\title{
Effect of Mode of Auxin Application on Rooting and Bud Break of Shea Tree (Vitellaria paradoxa) Cuttings
}

\section{Moses Okao1*, Lawrence Ogwal'1, Gloria Mutoni'1, Samuel Oyuko Alip¹, John Bosco Lamoris Okullo², Clement Akais 0kia ${ }^{3}$}

${ }^{1}$ Ngetta Zonal Agricultural Research and Development Institute, National Agricultural Research Organisation (NARO), Lira, Uganda

${ }^{2}$ College of Agricultural and Environmental Sciences, Makerere University, Kampala, Uganda

${ }^{3}$ World Agroforestry Centre (ICRAF), Kampala, Uganda

Email: ^mokao@naro.go.ug

How to cite this paper: Okao, M., Ogwal, L., Mutoni, G., Alip, S.O., Okullo, J.B.L. and Okia, C.A. (2016) Effect of Mode of Auxin Application on Rooting and Bud Break of Shea Tree (Vitellaria paradoxa) Cuttings. American Journal of Plant Sciences, 7, 21992208.

http://dx.doi.org/10.4236/ajps.2016.715194

Received: August 27, 2016

Accepted: November 6, 2016

Published: November 9, 2016

Copyright $\odot 2016$ by authors and Scientific Research Publishing Inc. This work is licensed under the Creative Commons Attribution International License (CC BY 4.0).

http://creativecommons.org/licenses/by/4.0/

\begin{abstract}
Vegetative propagation by stem cutting is an important technique applied for agricultural production where rooting success is one of the major aspects. A study to assess the effects of mode of application of rooting hormones (IBA) on adventitious root formation of $V$. paradoxa stem cuttings was conducted. Accordingly, four application methods were investigated in a $4 \times 3$ factorial experiment using a Completely Randomized Design (CRD). The application methods were: 24 -hour extended soak, foliar spraying, basal quick dip and delayed IBA application method. Thus, the parameters used to determine rooting success were mean root length and root number. The effect of these application methods on occurrence of bud break was also considered. On the whole, root length was observed to be a function of IBA concentration, whereby root length increased significantly $(P \leq 0.05)$ with an increment in IBA concentration. Stem cuttings subjected to $24-\mathrm{h}$ extended soak at $100 \mathrm{ppm}$ rooted best $(59.5 \% \pm 8.33 \%)$, where as foliar sprayed stem cuttings exhibited the worst rooting success $(11.9 \pm 3.06-23.8 \% \pm 4.16 \%)$. Bud break appeared to decrease with increasing IBA concentration and delaying IBA application enhanced rooting percentage of the quick dip method by $7.1 \%, 9.5 \%$ and $11.9 \%$ at $2500 \mathrm{ppm}, 3500 \mathrm{ppm}$ and $4500 \mathrm{ppm}$, respectively. The extended soak method of IBA application at $80 \mathrm{ppm}$ shows potential for large scale production of $V$. paradoxa through stem cuttings.
\end{abstract}

\section{Keywords}

IBA Mode of Application, Shea Tree, Extended Soak Method, Bud Break

\section{Introduction}

Vitellaria paradoxa (shea tree) is a wild fruit-bearing tree species of great socio-eco- 
nomic importance in Sub-Saharan Africa [1]. The shea tree has multitudinous uses ranging from consumption as a traditional food additive to utilization in the pharmaceutical, confectionary and cosmetic industries. Its demand is ever increasing inversely with the productivity and this has necessitated research into various propagation techniques such as grafting, cutting and layering.

According to [2], three methods of applying auxin to stem cuttings have been most common in commercial horticulture over the past 70 years. These are: the basal quickdip (concentrated-solution dip or quick-dip) method, the powder (talc or dust) application method, and the dilute soak (dilute-solution soaking) method. The basal quickdip and powder application methods tend to be most common, with the quick-dip generally considered to be the superior method of the two [3].

Some uncommon methods of auxin application include: injection; acid/base pretreatment, foliar sprays, and substrate application methods. According to [4], auxins can also be administered by injecting solutions of IBA or NAA into the xylem at either $10 \mathrm{~cm}$ from the plant base or $10 \mathrm{~cm}$ below the uppermost lateral shoot at 1 to 8 weeks before the cuttings are severed from the plants. [5] also found that rooting of hardwood cuttings can be promoted if they are dipped in either $2 \mathrm{~N}$ sulphuric acid for $20 \mathrm{sec}$ or in sodium hydroxide for $10 \mathrm{~min}$ prior to auxin application and placement into a rooting substrate.

As efforts towards vegetative propagation of shea tree via stem cuttings have usually centered on the basal quick dip method [6] [7] [8] [9], it means that merits of other auxin application methods had not yet been explored. Besides the standard practice of the basal quick dip method, there has also been vast evidence in literature that uncommon methods of auxin application could potentially increase plant sensitivity to exogenous auxins thereby enhancing adventitious root formation [2]. Since most research had only reported rooting response and neglected influence of auxin concentration on subsequent budbreak, this study aimed at closing these knowledge gaps by evaluating the response of $V$. paradoxa stem cuttings with other modes of auxin application.

\section{Materials and Methods}

\subsection{Study Area}

Experiments to determine the effect of auxin mode of application on rooting and budbreak of shea tree coppice cuttings were conducted at Ngetta Zonal Agricultural Research and development institute located in Lira district, Northern Uganda between March and July 2014.

\subsection{Stem Cutting Types and Preparation}

Coppice cuttings measuring $25 \mathrm{~cm}$ in length were obtained from 3 months old coppices of mature $V$. paradoxa trees; wrapped in damp manila paper, placed firmly in buckets and transported to the research station. Coppice cuttings have been chosen because coppicing helps to promote physiological juvenility in difficult-to-root tree species by producing shoots that root more readily [10]. The cuttings were then reduced to $12 \mathrm{~cm}$ 
in length and subjected to various IBA treatments prior to placing them firmly in a polythene propagator containing rooting substrate.

\subsection{Experimental Setup}

Subsequently, the $12 \mathrm{~cm}$ long shoot tip cuttings were used in a $4 \times 3$ factorial experiment ( 4 modes of IBA application $\times 3$ concentration levels) with 42 cuttings per treatment (Table 1). A Completely Randomized Design (CRD) was used with three replications [11].

The extended basal soak treatment involved bundling 21 stem cuttings together using rubber bands and placing the basal portion $(2 \mathrm{~cm})$ of the cuttings into dilute solutions of IBA for $24 \mathrm{hr}$ in a room with indirect lighting prior to insertion into the rooting substrate.

For the basal quick dips, the basal $1-2.5 \mathrm{~cm}$ portions of the cuttings were dipped for ten (10) seconds in the respective IBA concentrations before insertion into the rooting substrate. The different auxin concentrations and application techniques evaluated were based on the work of [2] who explored several methods of auxin application and their effect on adventitious root formation. The treatments did not include a control (cuttings with no IBA treatment) mainly because previous studies conducted on shea nut have shown poor rooting (1\%) without the use of rooting hormones [12] [13]. The different concentrations were prepared by dissolving IBA in $1 \mathrm{~N} \mathrm{NaOH}$. All cuttings with roots $\geq 1.0 \mathrm{~cm}$ were considered as rooted [14].

The stem cuttings were later housed in wooden propagation boxes lined with black polythene. These propagators were set up beneath a black shade net that provides $75 \%$ light intensity. Growth temperature ranged between $12.1^{\circ} \mathrm{C}$ and $32.0^{\circ} \mathrm{C}$. The rooting substrate comprised of a sterile vermiculite + perlite mixture $(1: 2 \mathrm{v} / \mathrm{v})$. Vermiculite was used because of its ability to hold water whereas perlite was included to improve aeration of the rooting substrate. Removal of dead cuttings and leaves was done on a weekly basis and watering was done only when humidity levels fell below $75 \%$. This is because at a higher humidity, cuttings appeared to deteriorate at the basal end, hence affecting their survival rate.

\subsection{Data Collection and Analysis}

Cuttings were evaluated for rooting 120 days upon establishment and data were collected on; number of rooted cuttings, quantity and length of developed roots [9] and occurrence

Table 1. Treatments for the four modes of auxin application.

\begin{tabular}{llccc}
\hline & \multicolumn{1}{c}{ Treatments in IBA } & \multicolumn{2}{c}{ Concentrations of IBA (ppm) } \\
\hline i) & 24 hr extended basal soak & 60 & 80 & 100 \\
ii) & Bi-weekly foliar spray with IBA & 40 & 60 & 80 \\
iii) & Basal quick dip & 2500 & 3500 & 4500 \\
iv) & Delayed IBA treatment & 2500 & 3500 & 4500 \\
\hline
\end{tabular}

Where IBA = Indole-3-butyric acid. 
of auxiliary bud break [15]. All data were entered and stored into Ms Excel (2007) computer package. Data were analyzed using R-system software, version 3.2.0 [16]. In order to investigate the quality of rooting success (root number and root length) between four modes of auxin application on shea stem cuttings, analysis of variance (ANOVA) was conducted [11]. Where treatments were found to be significantly different, the Tukey's Honestly Significant Difference (HSD) was used to make pair wise comparisons [17].

\section{Results}

Stem cuttings subjected to $24 \mathrm{~h}$ extended soak at $100 \mathrm{ppm}$ rooted best $(59.5 \% \pm 8.33 \%)$. This was followed by delayed IBA application $(52.4 \% \pm 4.36 \%-54.8 \% \pm 6.08 \%)$, basal quick dip $(42.9 \% \pm 7.23 \%-47.6 \% \pm 4.73 \%)$ and foliar sprays $(11.9 \% \pm 3.06 \%-23.8 \% \pm$ $4.16 \%$ ) in descending order. At the end of the experiment, foliar sprayed cuttings exhibited the largest proportion of dormant $(26.2 \% \pm 3.00 \%-35.7 \% \pm 4.04 \%)$ and dead cuttings $(42.9 \% \pm 8.96 \%-57.1 \% \pm 11.79 \%)$ altogether. Delaying IBA application enhanced rooting percentage of the quick dip method by $7.1 \%, 9.5 \%$ and $11.9 \%$ at 2500 ppm, $3500 \mathrm{ppm}$ and $4500 \mathrm{ppm}$ respectively. It also enhanced mean root length and roots per cutting (Figure 1, Table 2).

Cuttings that received the extended basal soak treatment not only produced the fewest $(2.8 \pm 0.68-3.3 \pm 0.68)$, but also the longest $(11.4 \pm 2.42-15.5 \pm 1.24 \mathrm{~cm})$ roots. Overall, root length was observed to be a function of IBA concentration; whereby root length increased significantly ( $\mathrm{P} \leq 0.05)$ with an increment in IBA concentration except for the quick dip method (Table 2).

Table 2. Effect of auxin mode of application on rooting and budbreak of shea stem cuttings.

\begin{tabular}{|c|c|c|c|c|c|c|}
\hline \multirow{2}{*}{\multicolumn{2}{|c|}{ Treatments }} & \multicolumn{2}{|c|}{ Rooting parameters } & \multirow{2}{*}{$\%$ bud break } & \multicolumn{2}{|c|}{ Pair wise comparisons } \\
\hline & & $\operatorname{ARL}(\mathrm{cm})$ & MRC & & $\operatorname{ARL}(\mathrm{cm})$ & MRC \\
\hline \multirow{3}{*}{ Extended soak (24 h) } & $60 \mathrm{ppm}$ & $11.4 \pm 2.42$ & $2.8 \pm 0.68$ & $61.2 \pm 4.58$ & \multirow{3}{*}{$13.7 \mathrm{a}$} & \multirow{3}{*}{$3.10 \mathrm{a}$} \\
\hline & $80 \mathrm{ppm}$ & $13.9 \pm 1.16$ & $3.2 \pm 0.73$ & $57.6 \pm 7.55$ & & \\
\hline & 100 ppm & $15.5 \pm 1.24$ & $3.3 \pm 0.68$ & $51.0 \pm 5.57$ & & \\
\hline \multirow{3}{*}{ Foliar spray } & $40 \mathrm{ppm}$ & $4.7 \pm 0.87$ & $4.5 \pm 0.55$ & $13.1 \pm 3.61$ & \multirow{3}{*}{$5.07 \mathrm{~b}$} & \multirow{3}{*}{$4.23 \mathrm{~b}$} \\
\hline & $60 \mathrm{ppm}$ & $5.4 \pm 0.85$ & $4.1 \pm 1.35$ & $8.4 \pm 0.00$ & & \\
\hline & $80 \mathrm{ppm}$ & $5.1 \pm 1.00$ & $4.1 \pm 1.29$ & $5.3 \pm 0.58$ & & \\
\hline \multirow{3}{*}{ Quick dip } & $2500 \mathrm{ppm}$ & $10.6 \pm 2.67$ & $6.2 \pm 1.61$ & $66.7 \pm 5.57$ & \multirow{3}{*}{$8.57 \mathrm{c}$} & \multirow{3}{*}{$5.70 \mathrm{c}$} \\
\hline & $3500 \mathrm{ppm}$ & $8.2 \pm 2.65$ & $5.9 \pm 2.18$ & $62.4 \pm 4.58$ & & \\
\hline & $4500 \mathrm{ppm}$ & $6.9 \pm 2.36$ & $5.1 \pm 1.86$ & $56.2 \pm 3.61$ & & \\
\hline \multirow{3}{*}{$\begin{array}{l}\text { Delayed IBA } \\
\text { application }\end{array}$} & $2500 \mathrm{ppm}$ & $11.6 \pm 3.15$ & $7.0 \pm 2.01$ & $74.1 \pm 4.36$ & \multirow{3}{*}{$12.24 \mathrm{a}$} & \multirow{3}{*}{$6.71 \mathrm{~d}$} \\
\hline & $3500 \mathrm{ppm}$ & $12.3 \pm 2.79$ & $6.6 \pm 2.37$ & $75.7 \pm 2.65$ & & \\
\hline & $4500 \mathrm{ppm}$ & $12.7 \pm 2.98$ & $6.6 \pm 2.19$ & $73.8 \pm 5.03$ & & \\
\hline \multicolumn{5}{|c|}{$\mathrm{HSD}_{0.05}$} & 1.47 & 0.93 \\
\hline
\end{tabular}

Data (rooting parameters and budbreak) represents means \pm SD of 3 replications per treatment. ARL: Average root length per cutting; MRC: Mean root count per cutting. Values in column with same letter did not differ significantly at $\mathrm{P}>0.05$ according to HSD. 


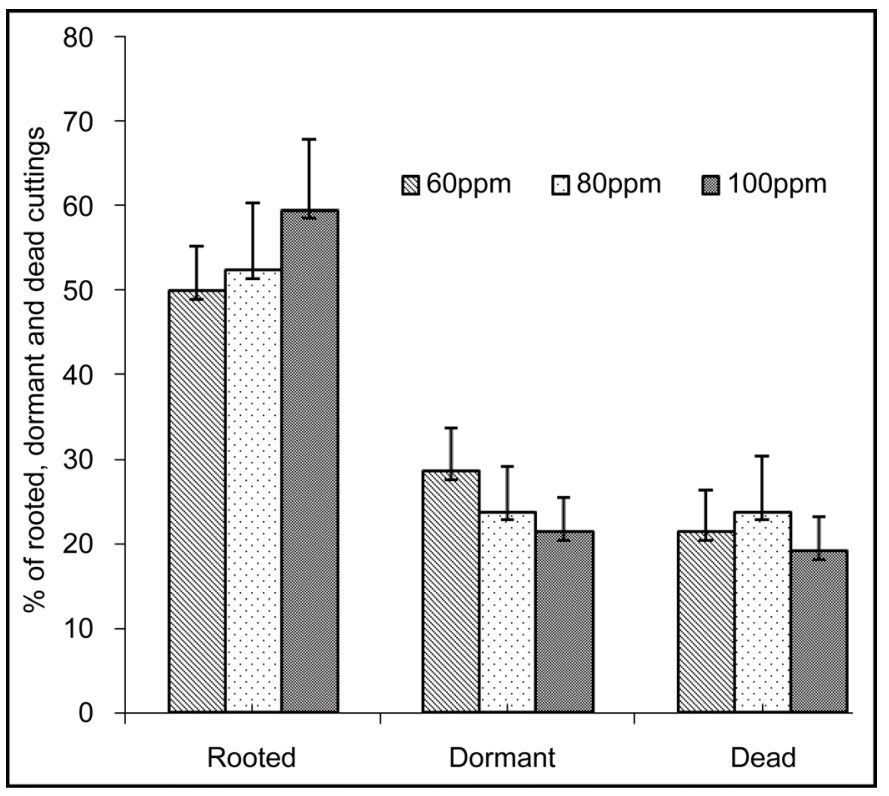

(a)

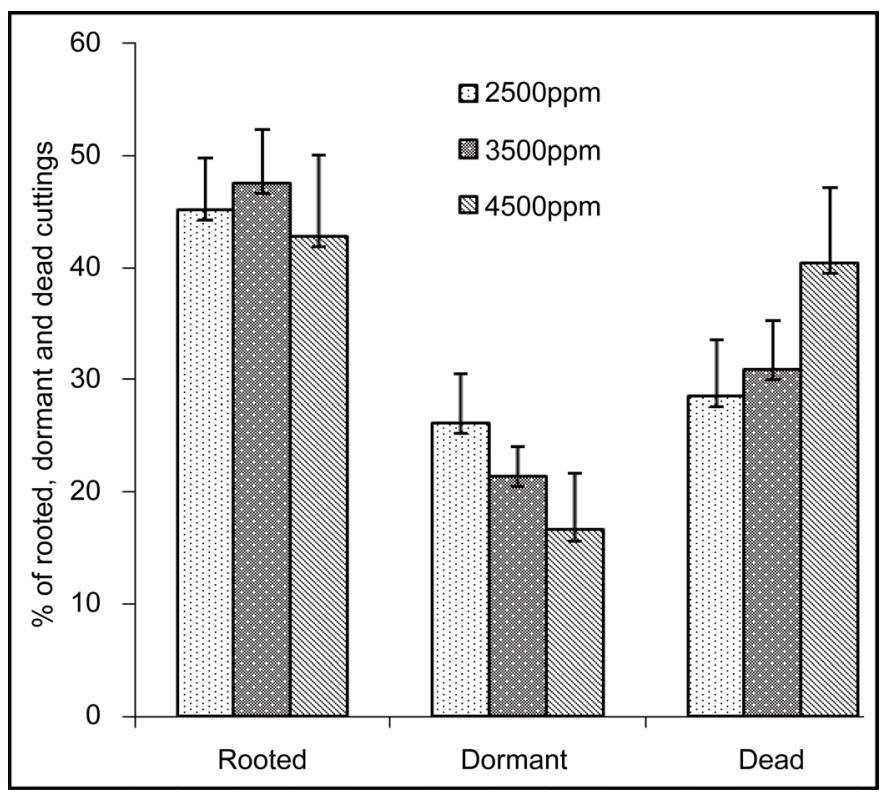

(c)

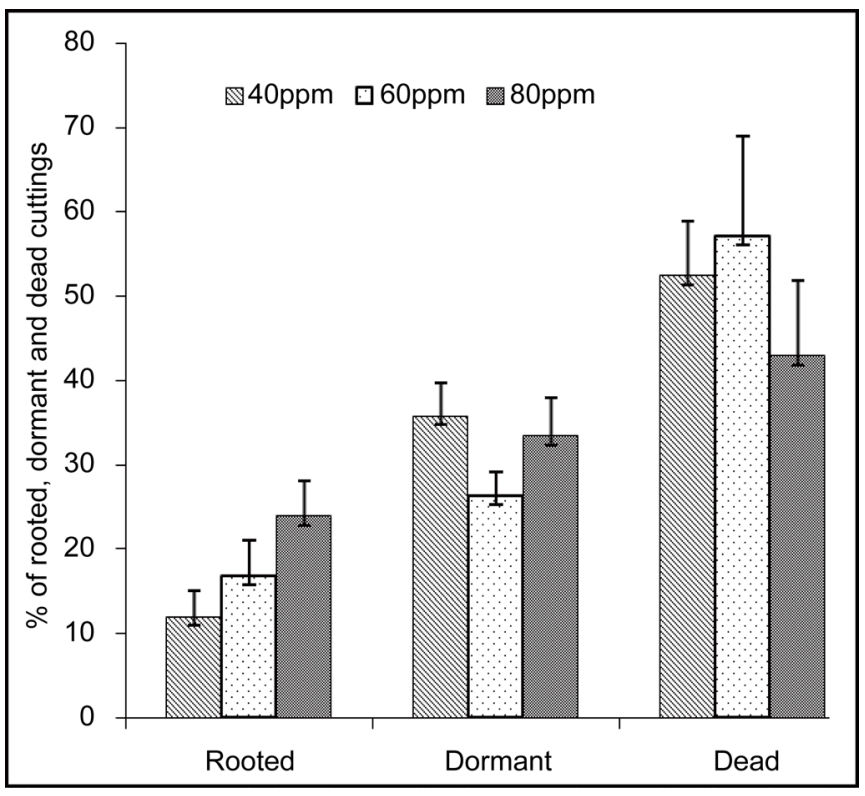

(b)

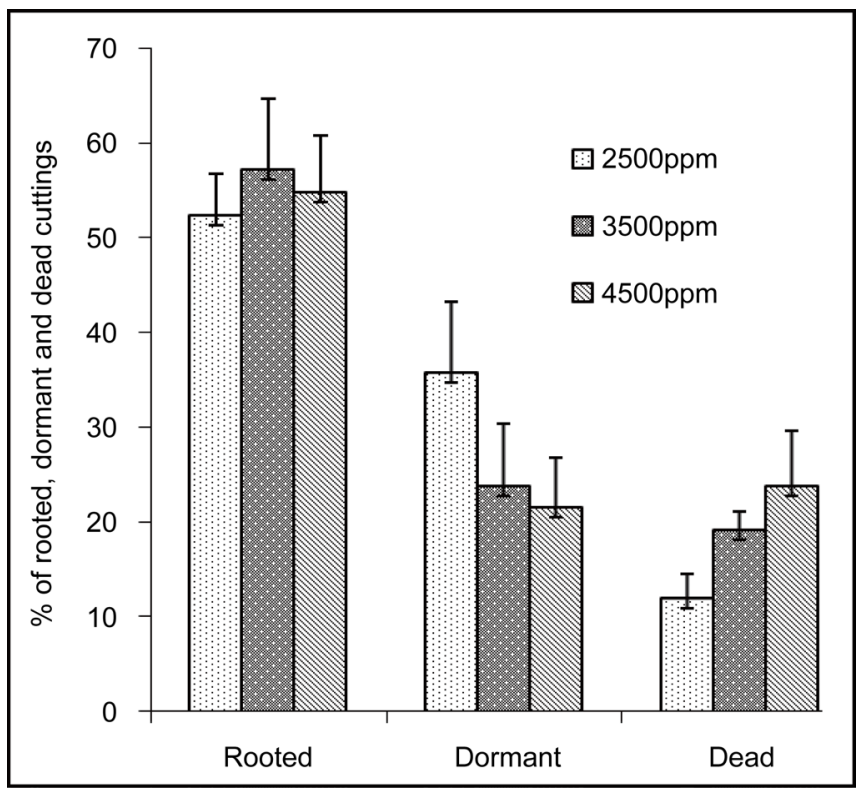

(d)

Figure 1. Effect of auxin mode of application on rooting success of shea stem cuttings. (a) Extended soak; (b) Foliar spray; (c) Quick dip method; (d) Delayed IBA application. Each point is the average value \pm SE of 3 replications per treatment.

Stem cuttings that exhibited the highest bud break were those subjected to delayed IBA treatment after 1 month. On the whole, bud break appeared to decrease with increasing IBA concentration (Table 2).

\section{Discussions}

Generally, root length was observed to be a function of IBA concentration; whereby root length increased with an increment in IBA concentration (except for the quick dip 
method). This finding concurs with a report by [18] who asserted that effectiveness of exogenous application of auxin in promoting rooting on stem cuttings is dependent on adequate absorption by plant tissue. Accordingly, the absorption of auxin solutions at the base of stem cuttings can be influenced by auxin concentration, with increasing concentration providing greater uptake. Indeed, the overall superiority of the extended basal soak (Figure 2(b)) over other application methods in terms of rooting percentage and root length can be attributed to increased uptake of auxin by the cuttings which may have enhanced these rooting parameters [2].

The basal quick dip method is considered as the most common way of applying auxin [19] [20]. The results of the rooting percentage, mean length and mean root count that ranged between $42.9 \%-47.6 \%, 6.9-10.6 \mathrm{~cm}$ and $5.1-6.2$ roots respectively for the quick dip method (Table 2) was found to be contrary to the finding by [9] whose work on rooting success of Vitellaria paradoxa stem cuttings indicated that the number of roots per cutting had increased with higher IBA concentration.

Although this was contrary to findings in the current investigation, rooting percentage in both experiments recorded similar results. The disparity could be a result of genetic variation between the different stem cuttings in the two studies. Cuttings used in the present investigation were of $V$. paradoxa ssp. nilotica whereas the previous study evaluated stem cuttings of $V$. paradoxa ssp. Paradoxa [21]. Accordingly, varying responses to plant growth regulators can be due to intrinsic factors based on the genetics of plant materials used [22].

On the other hand, the lowest rooting percentage of between $35.7 \%$ and $38.1 \%$, exhibited by the foliar sprayed cuttings (Figure 2), could be due to inadequate translocation of auxin (IBA) from the site of application (stem tips and leaves) to the site of adventitious root initiation. This is because exogenous auxins usually move acropetally in the xylem meaning that translocation in the xylem is unlikely to occur to any great extent when auxins are applied as foliar sprays unless when auxin is applied directly to the soil or to a cut plant part, providing direct access to the transpiration stream [2]. Another

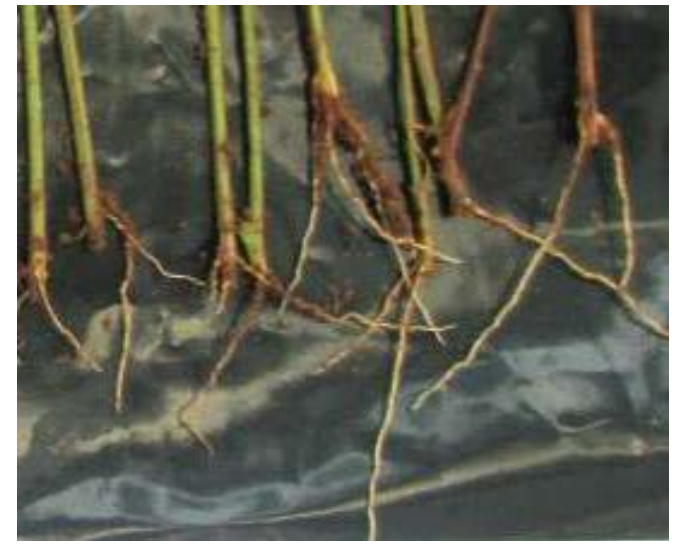

(a)

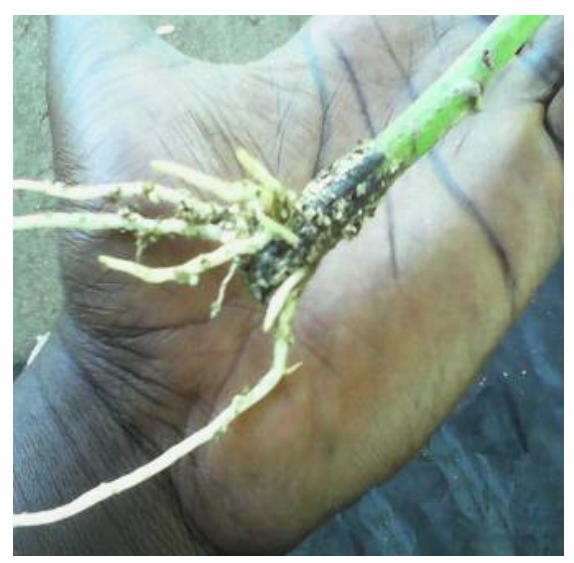

(b)

Figure 2. Root proliferation in stem cuttings subjected to (a) $24 \mathrm{hr}$ basal soak of IBA at $80 \mathrm{ppm}$; (b) Quick dip in IBA at 2500 ppm. 
line of argument by [20] is that auxins applied as foliar sprays are usually not retained long enough for adequate absorption to take place.

Despite this, foliar spray applications elsewhere [23] [24] gave better rooting success than those recorded in this study with $V$. paradoxa cuttings. A possible explanation could arise from the frequency of auxin application. In the other investigations, single foliar sprays were applied within $24 \mathrm{~h}$ of sticking the cuttings into the rooting substrate whereas in the current study, bi-weekly foliar sprays were conducted for one month during the experimental period. Since repeated spraying was found to produce negative effects on root and shoot development of Rosa spp. (red cascade rose) cuttings [25] it is likely that continued application of auxin may have had a negative influence on rooting success of $V$. paradoxa cuttings in this study.

Even when the use of delayed auxin treatment with stem cuttings has been rarely reported in most studies, in the current investigation; delayed IBA treatment delivered better rooting percentage $(52.4 \% \pm 4.36 \%-57.1 \% \pm 7.55 \%)$ than foliar application $(11.9 \% \pm 3.06 \%-23.8 \% \pm 4.16 \%)$ and quick dip method $(42.9 \% \pm 7.23 \%-47.6 \% \pm$ $4.73 \%)$. It also gave the highest mean number of roots per cutting $(6.6 \pm 2.19-7.0 \pm$ 2.01). A similar run of results was obtained by [19] when working with difficult-to-root cuttings of Eucalyptus nitens. In that study, root initiation occurred in response to a 48-hr basal soak in a solution of IBA at $20 \mathrm{mg} /$ liter (ppm), with the greatest response obtained when auxin was applied 4 or 5 weeks after the cuttings were inserted into the rooting substrates since early bud break (Figure 3 ) and shoot growth are vital for survival of propagated cuttings [26].

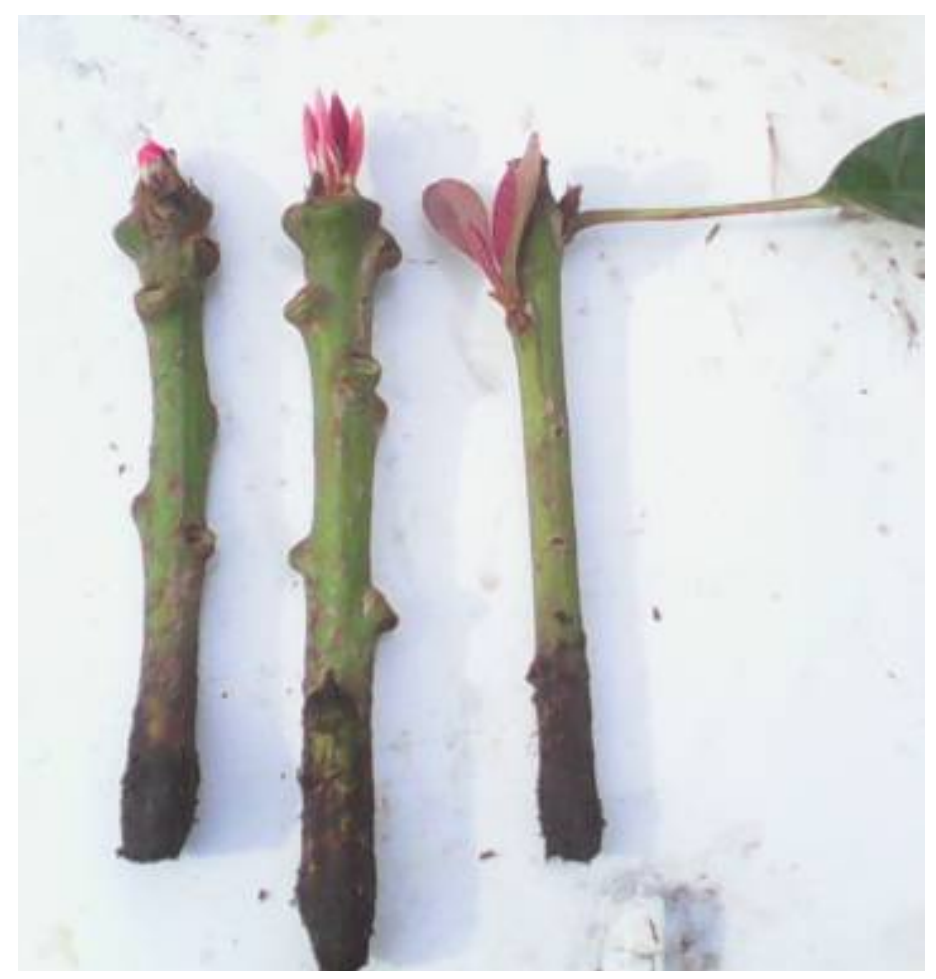

Figure 3. Budbreak of $V$. paradoxa stem cuttings prior to root formation. 
The decrease in bud break with increase in IBA concentration for all the treatments evaluated (Table 2) indicates that IBA strongly influences shoot development. A similar trend was observed by [15] in a study to examine the relationship between IBA concentration and bud break in Rosa hybrida cuttings whereby increase in IBA concentration (from 0 - $1200 \mathrm{ppm}$ ) subsequently reduced bud break. In fact, IBA treatment remarkably reduced bud break of cuttings such that, a concentration of IBA $\geq 600 \mathrm{ppm}$ almost completely inhibited budbreak of cuttings during the first four weeks in that study. This decrease in bud break could be attributed to ethylene synthesis stimulated by IBA. This is so because at $1000 \mathrm{ppm}$ IBA can stimulate more ethylene production that is responsible for delaying budbreak to a greater extent than the 500 ppm treatment. As control cuttings had the lowest ethylene level and highest percent budbreak, it implies that subsequent increase of IBA concentration in the present study might have resulted in ethylene production that eventually suppressed budbreak.

In general, exogenous auxin application usually influences rooting success by auxins exerting their effects in plant tissues located near the region of contact with the plant growth regulator [27]. These effects can also be related to the timing of IBA applications [19] as well as its concentration [28].

\section{Conclusion}

Based on percentage rooting, mean root number per cutting and average root length of $V$. paradoxa stem cuttings, the extended basal soak method/mode of auxin application studied produced the best results. $V$. paradoxa stem cuttings subjected to bi-weekly foliar sprays produced the poorest rooting success. Thus, the 24 -hr long soak method at $80 \mathrm{ppm}$ and delayed auxin application at $3500 \mathrm{ppm}$ are the recommended stem cutting propagation methods to be adapted for large scale propagation of $V$. paradoxa through stem cuttings. Nonetheless, given the economic significance of foliar spraying, more investigations into this application method need to be conducted.

\section{Acknowledgements}

The authors are grateful to Regional Universities Forum for Capacity Building in Agriculture (RUFORUM) and National Agricultural Research Organization (NARO) for providing financial assistance and research facilities to carry out this work.

\section{References}

[1] Sanou, H., Kambou, S., Teklehaimanot, Z., Dembélé, M., Yossi, H., Sina, S., Djingdia, L. and Bouvet, J.M. (2004) Vegetative Propagation of Vitellaria Paradoxa by Grafting. Agroforestry Systems, 60, 93-99. http://dx.doi.org/10.1023/B:AGFO.0000009408.03728.46

[2] Blythe, E.K., Sibley, J.L., Tilt, K.M. and Ruter, J.M. (2007) Methods of Auxin Application in Cutting Propagation: A Review of 70 Years of Scientific Discovery and Commercial Practice. Journal of Environmental Horticulture, 25, 166-179.

[3] Dirr, M.A. and Heuser Jr., C.W. (1987) The Reference Manual of Woody Plant Propagation: From Seed to Tissue Culture. Varsity Press, Inc., Athens.

[4] Leakey, R.R.B. (1992) Enhancement of Rooting Ability in Triplochiton scleroxylon by In- 
jecting Stockplants with Auxin. Forest Ecology and Management, 54, 305-313. http://dx.doi.org/10.1016/0378-1127(92)90019-6

[5] Lee, C.I., Paul, J.L. and Hackett, W.P. (1977) Promotion of Rooting in Stem Cuttings of Several Ornamental Plants by Pretreatment with Acid or Base. HortScience, 12, 41-42.

[6] Yeboah, J., Lowor, S.T. and Amoah, F.M. (2009) The Rooting Performance of Shea (Vitellaria paradoxa Gaertn) Stem Cuttings as Influenced by Wood Type, Sucrose and Rooting Hormone. Scientific Research and Essay, 4, 521-525.

[7] Yeboah, J., Akrofi, A.Y. and Owusu-Ansah, F. (2010) Influence of Selected Fungicides and Hormone on the Rooting Success of Shea (Vitellaria paradoxa Gaernt) Stem Cuttings. Agriculture and Biology Journal of North America, 1, 313-320. http://dx.doi.org/10.5251/abjna.2010.1.3.313.320

[8] Yeboah, J., Lowor, S.T., Amoah, F.M. and Owusu-Ansah, F. (2011) Propagating Structures and Some Factors That Affect the Rooting Performance of Shea (Vitellaria paradoxa Gaertn) Stem Cuttings. Agriculture and Biology Journal of North America, 2, 258-269. http://dx.doi.org/10.5251/abjna.2011.2.2.258.269

[9] Akakpo, D.B., Amissah, N., Yeboah, J. and Essie, B. (2014) Effect of Indole-3-Butyric Acid and Media Type on Adventitious Root Formation in Shea Nut Tree (Vitellaria paradoxa C. F. Gaertn.) Stem Cuttings. American Journal of Plant Sciences, 5, 313-318. http://dx.doi.org/10.4236/ajps.2014.53043

[10] Howard, B.H. (1994) Manipulating Rooting Potential in Stock Plants before Collecting Cuttings. In: Davis, T.D. and Haissig, B.E., Eds., Biology of Adventitious Root Formation, Plenum Press, New York, 123-142. http://dx.doi.org/10.1007/978-1-4757-9492-2_10

[11] Kirk, R.E. (2013) Experimental Design: Procedures for the Behavioral Sciences. 4th Edition, Sage, Thousand Oaks, Chapter 2, 26-40.

[12] Opoku-Ameyaw, K., Amoah, F.M. and Yeboa, J. (2000) Studies into Vegetative Propagation on the Sheanut Tree (Vitellaria paradoxa Gaertn). Journal of the Ghana Science Association, 4, 138-145.

[13] Yidana, J.A. (2004) Progress in Developing Technologies to Domesticate the Cultivation of Shea Tree (Vitellaria paradoxa L.) in Ghana. Agricultural and Food Science Journal of Ghana, 3, 249-268.

[14] Stenvall, N. (2006) Multiplication of Hybrid Aspen (Populus tremula L. $\times$ P. tremuloides Michx.) from Cuttings. Academic Dissertation, University of Helsinki, Faculty of Agriculture and Forestry, Helsinki.

[15] Quan, W.S. and Bassuk, N. (1991) Does IBA Inhibit Shoot Growth in Rooted Cuttings? Proceedings of the International Plant Propagators' Society, 41, 456-461.

[16] Venables, W.N. and Smith, D.N. (2009) An Introduction to R. Notes on R: A Programming Environment for Data Analysis and Graphics Version 2.9.0.

[17] Zar, J. (1999) Biostatistical Analysis. 4th Edition, Prentice Hall, Upper Saddle River, 663 p.

[18] Howard, B.H. (1985) Factors Affecting the Response of Leafless Winter Cuttings of Apple and Plum to IBA Applied in Powder Formulation. Journal of Horticultural Science, 60, 161-168. ttp://dx.doi.org/10.1080/14620316.1985.11515615

[19] Luckman, G.A. and Menary, R.C. (2002) Increased Root Initiation in Cuttings of Eucalyptus nitens by Delayed Auxin Application. Plant Growth Regulation, 38, 31-35. ttp://dx.doi.org/10.1023/A:1020926114165

[20] Blythe, E.K., Sibley, J.L, Tilt, K.M. and Ruter, J.M. (2004) Auxin Application to Stem Cuttings of Selected Woody Landscape Plants by Incorporation into a Stabilized Organic Rooting Substrate. Journal of Environmental Horticulture, 22, 63-70. 
[21] Allal, F., Sanou, H., Millet, L., Vaillant, A., Camus-Kulandaivelu, L., Logossa, Z.A., Lefevre, F. and Bouvet, J.M. (2011) Past Climate Changes Explain the Phylo-Geography of Vitellaria paradoxa over Africa. Heredity, 107, 174-186. http://dx.doi.org/10.1038/hdy.2011.5

[22] Bennett, I.J., McDavid, D.A.J. and McComb, J.A. (2003) The Influence of Ammonium Nitrate, $\mathrm{pH}$ and Indolebutyric Acid on Root Induction and Survival in Soil of Micropropagated Eucalyptus globulus. Biologia Plantarum, 47, 355-360.

http://dx.doi.org/10.1023/B:BIOP.0000023877.21262.a5

[23] Hamza, M.A. (2014) Evaluate Use Different Applications and Concentrations of Indole Butyric Acid for Vegetative Propagation of Petunia Hybrid. Plant Nature and Science, 12, 102-107.

[24] Drahn, S.R. (2007). Auxin Application via Foliar Sprays. Proceedings of the International Plant Propagators'Society, 57, 44-48. http://hortus.com/IBAarticles/Drahn_2007.pdf

[25] Blythe, E.K., Sibley, J.L., Tilt, K.M. and Ruter, J.M. (2004b) Rooting of Rose Cuttings in Response to Foliar Applications of Auxin and Surfactant. HortTechnology, 14, 479-483.

[26] Hartmann, H.H., Kester, D.E. and Davies Jr., F.T. (1990) Plant Propagation Principles and Practices. 5th Edition, Prentice Hall, Eaglewood Cliffs, 232-233.

[27] Husen, A. and Pal, M. (2007) Metabolic Changes during Adventitious Root Primordium Development in Tectona grandis Linn. f. (Teak) Cuttings as Affected by Age of Donor Plants and Auxin (IBA and NAA) Treatment. New Forests, 33, 309-323.

http://dx.doi.org/10.1007/s11056-006-9030-7

[28] Wendling, I., Brondani, G.E., Dutra, L.F. and Hansel, F.A. (2009) Mini-Cuttings Technique: A New ex Vitro Method for Clonal Propagation of Sweetgum. New Forests, 39, 343-353. http://dx.doi.org/10.1007/s11056-009-9175-2

\section{Submit or recommend next manuscript to SCIRP and we will provide best service} for you:

Accepting pre-submission inquiries through Email, Facebook, LinkedIn, Twitter, etc.

A wide selection of journals (inclusive of 9 subjects, more than 200 journals)

Providing 24-hour high-quality service

User-friendly online submission system

Fair and swift peer-review system

Efficient typesetting and proofreading procedure

Display of the result of downloads and visits, as well as the number of cited articles

Maximum dissemination of your research work

Submit your manuscript at: http://papersubmission.scirp.org/

Or contact ajps@scirp.org 